\title{
Triggers of Organizational Change: Duration, Previous Changes, and Environment
}

\section{Authors: Agnieszka Bielinska-Kwapisz}

This is an Accepted Manuscript of an article published in Journal of Change Managementon March 26, 2014, available online: http://www.tandfonline.com/10.1080/14697017.2014.885461

Bielinska-Kwapisz, Agnieszka. "Triggers of Organizational Change: Duration, Previous Changes, and Environment." Journal of Change Management 14, no. 3 (March 26, 2014): 405-424. doi: 10.1080/14697017.2014.885461.

Made available through Montana State University's $\underline{\text { ScholarWorks }}$ 


\title{
Triggers of Organizational Change: Duration, Previous Changes, and Environment
}

\author{
AGNIESZKA BIELINSKA-KWAPISZ
}

Jake Jabs College of Business \& Entrepreneurship, Montana State University, Bozeman, MT 59717, USA

\begin{abstract}
This article explores triggers of organizational change. In particular, how the likelihood of future changes is influenced by duration between the changes, the number of previous changes, and the surrounding conditions. Rule changes are analysed by examining factors that influence US states to update their excise tax rates on beer and cigarettes using panel data for 48 contiguous states. We provide evidence in favour of the deceleration hypothesis: prior changes of a given type decrease the likelihood of a subsequent change of the same type. We found support that the likelihood of organizational change increases with duration (the time between the changes). States updated their beer and cigarette tax rates in response to accumulation of inflation not letting the rates to become obsolete. Finally, our results indicate that changes in surrounding conditions positively influence the probability of change. State legislators take the opportunity of changes in the neighbouring states to change their own taxes. A logit model to estimate the probability of change and a hazard model to estimate the time to change are employed.
\end{abstract}

KeY Words: Organizational change, causes of change, deceleration hypothesis, repetitive momentum hypotheses, duration, state excise taxes, hazard models

\section{Introduction}

The capability of organizations to innovate and change is becoming more and more important in the times of globalization, de-regulation, and competitive pressure. A survey of executives from around the world by McKinsey \& Company (2008) found that only by changing constantly could organizations hope to survive. However, studies show that up to $70 \%$ of all change initiatives 
fail (Burnes \& Jackson, 2011; Hammer \& Champy, 1993; Higgs \& Rowland 2005, Kotter, 1990; McKinsey \& Company, 2008; Rogers, Meehan, \& Tanner 2006). Therefore, exploring reasons behind conducting a successful change initiative is an important topic for private and public organizations (Baraldi, Kalyal, Berntson, Näswall, \& Sverke, 2010; Parry, Kirsch, Carey, \& Shaw, 2013). However, as pointed out by By (2005) there is a lack of empirical research on change management. One branch of research focuses on the consequences of change (risk of organizational failure as a consequence of change). The other, concentrates on the causes of change. Within this research field, of a particular interest is whether the number of prior rule changes, rule obsolescence, and the surrounding environment influence the likelihood of future rule changes - the topic addressed in this paper. Exploring these factors behind rule changes might provide us with new perspectives on bureaucracies and ways to avoid inefficiencies. We study change using US states excise tax rates on beer and cigarettes. Therefore, our analysis also sheds light on designing effective tax policies, obtaining public resources for governments and, even modifying the economic agents' consumption. The study of change is relatively young and Pettigrew, Woodman, and Cameron (2001) called for new research and bigger collaboration between social science and management research. Also, Dacin, Goodstein, and Scott (2002, p. 45) believed that 'the topic of institutional change has emerged as a central focus for organizational researchers'.

Prior change was identified as one of the factors influencing the probability of further change (Amburgey, Kelly, \& Barnett, 1993; Beck, Brüderl, \& Woywode, 2008; Dobrev, Kim, \& Hannan, 2001; Kelly \& Amburgey, 1991). In a recent paper Beck, Brüderl, and Woywode (2008) showed that the change propensity decreases as changes accumulate (the deceleration hypothesis) and that the alternative view (the repetitive momentum hypothesis), that prior changes increase the likelihood of future changes, might be a result of a bias introduced by unobserved heterogeneity. In this paper, we tested the model of change by controlling for heterogeneity in our data. That is, our analyses included states' fixed effects to account for unmeasured factors influencing changes in tax rates. Previous studies on the subject concentrate on three types of organizational changes: changes in companies' rules, leadership, and strategies. ${ }^{1}$ Beck, Brüderl, and Woywode (2008) and Beck and Kieser (2003) found significant and negative effect of the number of previous changes on rule change probability using data on the personnel rules of a German bank (which were merged, reordered, reformulated, or abolished altogether). Schulz (1998) estimated the rate of revision of administrative rules of a large US research university using a hazard model and found the number of previous rules revisions to be positive and significant. Other studies aimed at analysing the change in companies' leadership. For example, Ocasio (1999) used data from 120 US industrial corporations listed in the Moody's Industrial Directory and found the past number of insider chief executive officer (CEO) successions to be positively related to the rate of the CEO successions. Beck, Brüderl, and Woywode (2008) showed a negative effect in coach replacement in Bundesliga soccer clubs. Finally, Delacroix and Swaminathan (1991) analysed change in companies' strategies. They explored three kinds of organizational change: brand-portfolio changes, product-line change, and change in land ownership status in the 
California wine industry. They found positive and significant effect of the number of preceding changes of the same kind on the probability of subsequent change. Except for Beck, Brüderl, and Woywode (2008) and Beck and Kieser (2003) no other study controlled for companies' fixed effects.

The other factor that can influence the likelihood of organizational change is the time between the rule changes. As time elapses, rules can become obsolete. Schulz and Beck (2000) compared duration dependence of rule changes at Stanford University to those at a German bank. They found similarities in effects of many covariates in both settings but the effect of duration dependence was different. Later, Schulz (2003) re-examined the data and concluded that organizational tolerance for obsolescence can delay changes of rules. Rule obsolescence was not closely monitored at the bank as opposed to the university where rule making process was highly centralized and monitored by the editor of the rule book.

Environmental changes can also influence the probability that the rules will be updated or changed. Since rules are established in a specific context at a specific historical time, as time passes new conditions may emerge and rules may be updated accordingly. The emergence of new conditions may be affected by laws, other organizations, new technologies, the general public, clients of the organization, suppliers, etc. (Schulz, 1998). Also, current business environment sees significant changes in globalization, changing demographics, higher employee involvement, new information, and technology (Frantz, 2004). Brittain (1989), using data from the semiconductor industry, showed that organizational learning is 'social' and is realized through the development of external social ties.

In this paper we study rule changes on the example of US states' excise taxes on beer and cigarettes controlling for states' fixed effects. States do not change their taxes very often. From 1933 to 2011, Nebraska has changed its beer tax rates 10 times - the most often among all states. New York and Washington followed with nine changes. On the other hand, during the same 78 years, Louisiana and Wisconsin have changed their beer tax rates only once and Ohio and Pennsylvania only twice. Still, New York's beer tax rate of $\$ 4.34 /$ barrel is much lower than Louisiana's tax of $\$ 10 /$ barrel. We observe similar variation in cigarette tax rates. The nation's first state-level cigarette excise tax was enacted in Iowa in 1921. Cigarette tax rates have been changed most often in Washington, Rhode Island, and New Hampshire: 12 times in 41 years. States that have not changed their cigarette tax rates for about the third of a century are: Virginia (1970-2004), Tennessee (1970-2003 years), Kentucky (1971-2005), and Georgia (1971-2003). The Center for Science in the Public Interest (CSPI, 2004) reports that

During the past several years, proposals to increase beer taxes have multiplied in state capitals. A few of them have even been successful. Many state efforts, however, have been hamstrung by a lack of information - about the relationship of a state's taxes to its neighbor states and national standards ( ... ).

Unlike the previous literature, we estimated the probability of change in tax rates and not the levels of tax rates. Compared to previous studies, we used a much longer sample covering 44 years (1967-2011) for beer taxes and 41 years (1970-2011) for cigarette taxes. Several authors estimated factors that affect levels of excise 
tax rates. For example, Bielinska-Kwapisz (2011) estimated the levels of state excise tax rates on beer, cigarettes, and gasoline using US data from 1982 to 2003 and found evidence of tax competition between neighbouring states for cigarette and gasoline tax rates. Devereux, Lockwood, and Redoano (2007) used a panel of US data from 1977 to 1997 and found evidence of cigarette tax competition between states. Nelson (2002) estimated US states' revenue shares from taxes on cigarettes, alcoholic beverages, beer, distilled liquor, motor fuel, and insurance and found evidence of between states tax competition for cigarette taxes, motor fuel taxes, and insurance premiums but not for beer or liquor tax revenues. Rork (2003) found that tax rates with relatively mobile tax bases (cigarette, gas, and corporate income taxes) increase and taxes with relatively immobile tax bases (personal income and sales tax) decrease while neighbouring states increase their rates. ${ }^{2}$

In the following section we discuss the theory and formulate our research questions. Next, we estimate logit models to show what factors influence the probability of change. In the second part of the paper, we estimate the time between changes by applying the hazard model. The rest of the paper is organized into four sections devoted to theory, data, results, and conclusions.

\section{Theory Development}

Rules are the most basic structural elements of organizations. They provide readily available procedures for the enactment of organizational decisions and solutions to typical problems (Cohen, March, \& Olsen, 1972; Kieser, Beck, \& Tainio, 2001; Kieser \& Walgenbach, 2003; March \& Olsen, 1976; Ocasio, 1999). Rules control organizational processes and increase their predictability (Beck \& Kieser, 2003; Weber, 1968). Therefore, as noted by Beck, Brüderl, and Woywode (2008), altering these elements is equivalent to internal organizational change at a very basic structural level. In this study we focus on three types of triggers of rules change: prior changes, surrounding conditions, and rules obsolescence.

One aspect of rule changes is their duration dependence: the effect of waiting time between changes on the likelihood of organizational change. The fundamental question is whether the likelihood of rule changes decrease or increase with duration (or 'waiting time'). The empirical literature failed to generate a definitive answer. The institutional theory provides the most compelling argument explaining why change propensity would decrease with duration. On the other hand, the obsolescence theory best explains why duration may increase the likelihood of future changes. According to the institutional (or permanence theory), rules, once put in force, attain increasing permanence (Zucker, 1987), they are taken for granted (DiMaggio \& Powell, 1991), and any effort to change them is met with resistance from habits, traditions, or sentimental commitments (Schulz, 2003). Therefore, according to institutional predictions the likelihood of rule changes (as well as revisions and suspensions) should decrease with duration (waiting time between changes). The institutional theory provides the strongest arguments for the permanence position (Schulz, 2003). As a result of institutionalization, rules become stable and sustained over long periods of time without continuous justification (Zucker, 1987). On the other hand, the organizational learning or obsolescence theory asserts that rules are repositories of organizational 
knowledge. Organizations adapt to the environment by creating rules that retain valuable solutions and, as time passes and surrounding conditions change, the rules become obsolete and must be updated (Schultz, 1992, 1988). Each revision of the rule re-starts the 'obsolescence clock' (Schulz, 2003). Therefore, according to obsolescence mechanisms, the likelihood of change should increase with duration. We formulated our first research question in the following way:

\section{Research Question 1: Do rule obsolescence triggers change?}

State excise taxes on beer and cigarettes are set in dollar terms. Therefore, their value decreases in time eventually rending them obsolete. We measure the level of this obsolescence by the increase in inflation since the last change. We re-start the 'obsolescence clock' after every change. States may choose to update their tax rates to stay ahead of the 'obsolescence' clock. Alternatively, the tax rates may become 'institutionalized' and any attempt to change them may be met with resistance from voters.

Organizations' experience in dealing with rule changes may also influence the propensity to change as suggested by the organizational learning theory (Beck, Brüderl, \& Woywode, 2008; Cyert \& March, 1963; Nelson \& Winter, 1982). 'In short, organizations learn to change by changing.' (Amburgey et al., 1993, p. 54). Organizations that change their rules more often learn how to change them, and the likelihood of future changes may increase (the repetitive momentum hypothesis). On the other hand, organizations that changed their rules more often in the past learn how to set rules so they do not require updating for a longer period of time (Beck, Brüderl, \& Woywode, 2008). Change is aimed at improving organizational structures and processes. Therefore, the probability of future change decreases, supporting the deceleration hypothesis. Since previous literature does not offer a definite answer we formulate the following research question:

Research Question 2: Do prior changes of a given type increase (the repetitive momentum hypothesis) or decrease (the deceleration hypothesis) the likelihood of a subsequent change of the same type?

States' legislators may learn how to successfully pass a tax rate increase legislation if they have more experience doing this in the past. Alternatively, with more experience in changing tax rates, legislators may do not need to (e.g. by setting rates high enough) or do not want to (e.g. there is no demand for higher taxes) go through the legislative process for a long time in the future.

Similarly, changes in the surrounding environment can influence the likelihood of rule change in two opposite ways. On one hand, rules may have to be updated when new opportunities have to be exploited, when participants found ways to circumvent rules, or when rules become a liability to the legitimacy of organization. On the other hand, rules may be less likely to change when some rules become the cornerstone of core competencies of organizations (e.g. Nordstrom's customer service procedures), or when rules become a source of accountability and reliability in times of increasing turbulence (e.g. Federal Aviation Administration (FAA) regulations after deregulation of the airline industry), or when 
rules become the foundation for other rules created at later points in time (constitutional rules, organizational missions; Schulz, 1998, p. 243). Therefore, whether the surrounding environment triggers change should be verified empirically.

Research Question 3: Do shifts in surrounding conditions increase the probability of change?

We measure the surrounding conditions by the change in neighbouring states' tax rates and the presence of an election year. For political reasons, states may be more likely to increase their tax rates when voters see similar changes in neighbouring states. On the other hand, states may want to attract visitors and neighbouring traffic by keeping their rates unchanged. Election year may not be a very likely time to increase tax rates unless tax rates on alcohol and cigarettes are seen as 'sin' taxes by voters (e.g. Utah's big Mormon population).

\section{Methods}

\section{Data}

We examined panel data on states' alcohol and cigarette taxes in 48 US states (excluding District of Columbia, Hawaii, and Alaska) from 1967 to 2011 for beer and from 1970 to 2011 for cigarette taxes. ${ }^{3}$ Beer tax rates are from Beer Institute Brewers' Almanac (Ponicki, 2004) and we used nominal off-premise state beer excise tax rates in dollars per 31 gallon barrel. ${ }^{4}$ Cigarette tax rates before 1970 were obtained from the State Cancer Legislative Database Program and after 1970 from the Centers for Disease Control and Prevention database.

To assess the effects of previous changes on the probability of future change, we constructed a variable, 'the number of preceding changes'. This variable is set to 0 at the first year of data and it takes a value of 1 in the year following the first change, of 2 in the year following the second change, and so on. In line with previous research, this variable is converted to a logarithm form (after adding 0.01 to all data because of the presence of zeros). A negative and significant coefficient on this variable would offer support of deceleration hypothesis (when the change propensity decreases as changes accumulate) while the positive coefficient would offer a support of the repetitive momentum hypothesis (when the change propensity increases as changes accumulate).

To capture the effect of duration between changes on the probability of future change, we constructed an 'inflation' variable. For each year and state, the accumulated inflation was computed as a percentage change in the Consumer Price Index (CPI) from the last year the tax rate was changed. This variable re-sets in the first year after the change. As explained in the theory development section, prior explorations of the effect of duration have emphasized either (a) institutional predictions when the likelihood of rule changes decreases with duration and the coefficient on the 'inflation' variable is negative; or (b) obsolescence mechanisms when the likelihood of change increases with duration and the coefficient on the 'inflation' is positive. 
The variable 'neighbourhood change' takes a value of 1 if there was a change in the tax rates in any of the geographically neighbouring states and zero otherwise. The governor election dummy takes value of one in election years and zero otherwise.

We present basic descriptive statistics and correlations in Tables 1 and 2 and histograms on Figures 1 and 2. Additionally, our original specification included the following control variables which were insignificant and by excluding them we improved the fit of the model: states' surplus, population over 65, young population between 18 and 29 years old, income, Democratic House and Senate, Democratic Governor, minimum drinking age, and percentage of Hotels and Motels in GSP.

As shown in Figure 1, there were 8 states that have not changed their beer taxes during the 44 years studied (from 1967 to 2011). These include: GA, ID, KY, LA, ND, PA, WV, and WY. On the other hand, states that changed their taxes most often (8 times) were WA, NE and NY. Most of the states (31\%) changed their beer tax rates two times in 44 years.

As for the cigarette tax rates (Figure 2), the number of changes ranged from 2 to 12 with the most of the states $(77 \%)$ changing its tax rates on cigarettes $2-7$ times in 41 years.

Table 1. Descriptive statistics and correlations for beer $(n=2,160)$ : 1967-2011 over 48 states

\begin{tabular}{|c|c|c|c|c|c|c|c|c|}
\hline Variable & Mean & St. dev. & Min & Max & 1. & 2. & 3. & 4. \\
\hline 1. Change in beer tax & 0.05 & 0.22 & 0 & 1 & 1 & & & \\
\hline $\begin{array}{l}\text { 2. Log (number of previous } \\
\text { changes) }^{\mathrm{a}}\end{array}$ & -0.43 & 1.45 & -2.30 & 2.09 & 0.003 & 1 & & \\
\hline $\begin{array}{l}\text { 3. Neighbourhood } \\
\text { change }\end{array}$ & 0.19 & 0.40 & 0 & 1 & $0.07^{*}$ & $-0.12^{* *}$ & 1 & \\
\hline 4. Inflation & 146.4 & 175.5 & 1.56 & 955 & -0.05 & $-0.46^{* *}$ & 0.01 & 1 \\
\hline 5. Election & 0.26 & 0.44 & 0 & 1 & -0.04 & 0.02 & -0.02 & $-0.01 \quad 1$ \\
\hline
\end{tabular}

${ }^{\mathrm{a} B e f o r e ~ t a k i n g ~ l o g a r i t h m, ~} 0.01$ was added since some values were zeros.

* Significant at $0.05 \%$ level.

** Significant at $0.01 \%$ level.

Table 2. Descriptive statistics and correlations for cigarettes $(n=2,016)$ : $1970-2011$ over 48 states

\begin{tabular}{lrrrrrrrrr}
\hline Variable & Mean St. dev. & Min & $\operatorname{Max}$ & 1. & 2. & 3. & 4. & 5. \\
\hline 1. Change in cigarette tax & 0.14 & 0.35 & 0 & 1 & 1 & & & \\
2. Log (number of previous & 0.36 & 1.40 & -2.30 & 2.49 & 0.06 & 1 & & \\
$\quad$ changes) & & & & & & & & \\
3. Neighbourhood change & 0.40 & 0.50 & 0 & 1 & $0.17^{* *}$ & 0.06 & 1 & & \\
4. Inflation & 50.00 & 73.80 & -0.36 & 483 & $-0.03^{*}$ & $-0.50^{* *}$ & -0.05 & 1 & \\
5. Election & 0.27 & 0.45 & 0 & 1 & -0.02 & -0.02 & 0.003 & -0.02 & 1 \\
\hline
\end{tabular}

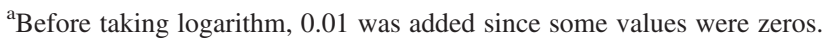

* Significant at $0.05 \%$ level.

${ }^{* *}$ Significant at $0.01 \%$ level. 


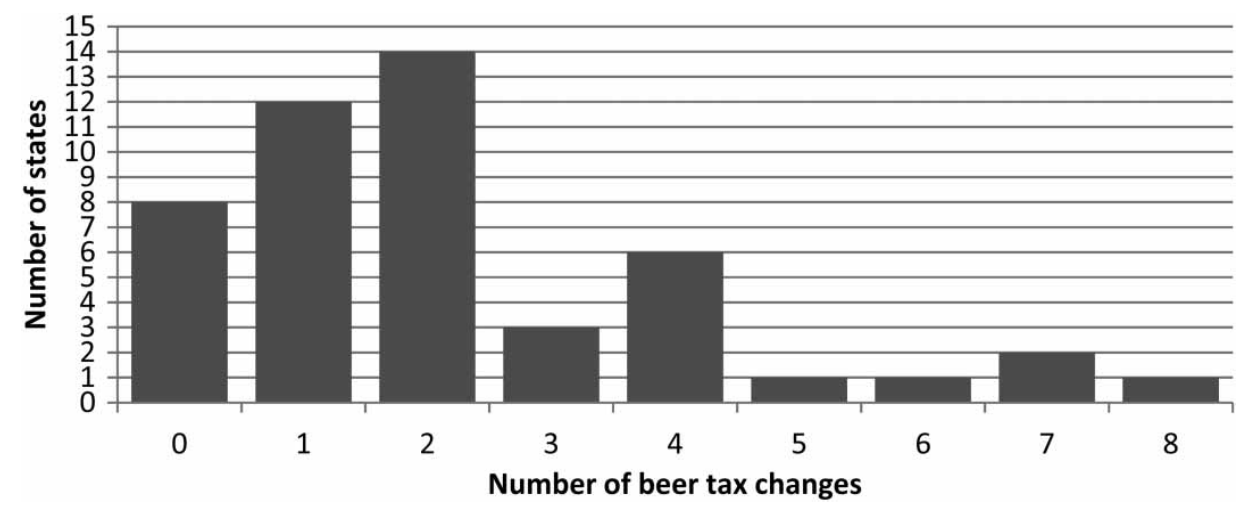

Figure 1. Histogram: the number of times state changed their beer taxes (1967-2011).

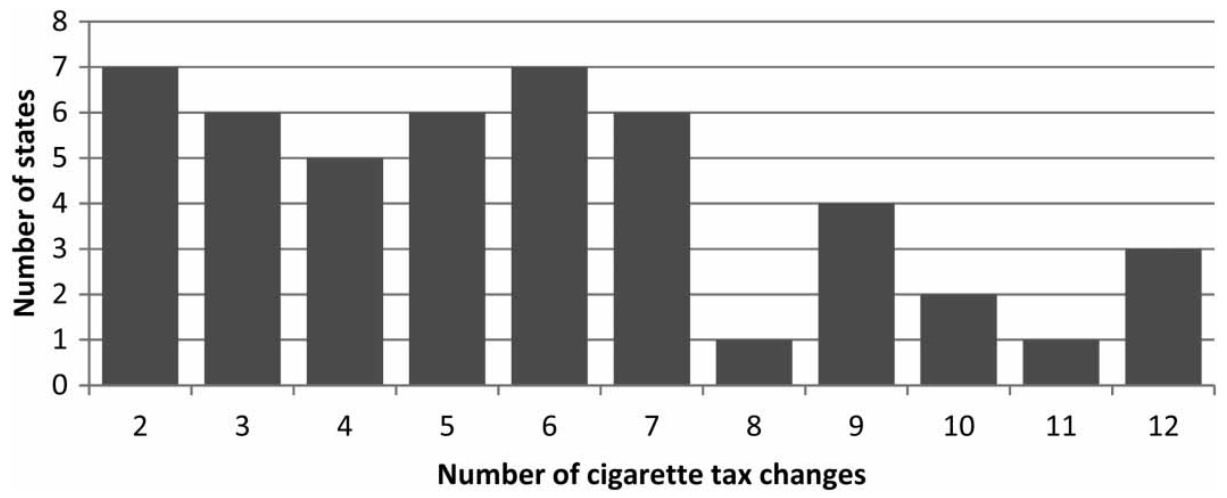

Figure 2. Histogram: the number of times state changed their cigarette taxes (1970-2011).

\section{Procedures: binary logit models}

Our dependent variable is a binary choice coded as one when a given state in a given year changed its tax rate and zero otherwise. We estimated the probability of a change in a given year and in a given state: $\operatorname{Prob}$ (change occurs) or $\operatorname{Prob}\left(y_{i t}=\right.$ 1 ), where $i$ is a state and $t$ is a year. We believe that a set of factors included in the vector $x$ explains this probability, therefore $\operatorname{Prob}\left(y_{i t}=1 \mathrm{I} x\right)=F(x, \beta)$ where $\beta$ 's are the parameters to be estimated. We assumed the logistic distribution, therefore $F(x, \beta)=\left(\left(e^{x^{\prime} \beta}\right) /\left(1+e^{x^{\prime} \beta}\right)\right)$ and we used the maximum likelihood method. Beck, Brüderl, and Woywode (2008) criticized previous studies for not accounting for unobserved heterogeneity: some organizations or states may have a higher inherent propensity to change than others. To correct for this, one has to use panel data (instead of cross-sectional data) and estimate a fixed-effects model. Therefore, our function $F$ becomes $F(x, \beta)=\left(\left(e^{x^{\prime} \beta+\mu_{i}}\right) /\left(1+e^{x^{\prime} \beta+\mu_{i}}\right)\right)$, where $\mu_{i}$ are state fixed effects that control for unmeasured factors. The vector $x$ consists of the following variables: the number of previous changes, the binary variable that equals one when there is a change in tax rate in the neighbouring states, 
the accumulated inflation since the last change, and the governor election dummy that takes value of one in election years and zero otherwise.

\section{Results}

We report our main results in Tables 3 and 4. Two models are presented to illustrate differences in estimation with and without fixed effects. The first columns present pooled models without fixed effects and second columns present panel data models with fixed effects. Therefore, our main results are reported in the second columns. The regression results from the first columns for beer and cigarette tax rates point to the shortcomings of the studies not controlling for the fixed effects: the coefficient on the number of previous changes is either positive (beer) or insignificant (cigarettes). However, the fixed-effects panel data binominal logit estimations give negative and significant coefficients in both regressions confirming Beck, Brüderl, and Woywode's (2008) deceleration hypothesis: prior changes of a given type decrease the likelihood of a subsequent change of the same type while controlling for unobserved heterogeneity. Our results suggest that states learn from the past and update their tax rates to last for more years.

Moreover, the accumulated inflation is the most important factor in the decisions by states to change their alcohol and cigarette taxes. States set their taxes in the amount of dollars per barrel for beer and cents per pack for cigarettes. Therefore, they need to update their rates to keep up with the inflation.

Additionally, the results in Tables 3 and 4 show that states change their tax rates when they see changes in the neighbouring states. States need to compete for beer and cigarette tax base because cross-border shopping is wieldy observed, especially in the case of cigarettes which are easy to transport. Therefore, the best time for states to increase their rates is when there is an increase in the neighbouring states; also, it may be politically easier to raise the tax rate when voters see

Table 3. Estimation results. Dependent variable is the change in beer tax rate

\begin{tabular}{lcc}
\hline Variable & Pooled model & Panel data binomial logit \\
\hline Log (number of previous changes) & $0.398^{*}(1.65)$ & $-0.663^{* *}(2.174)$ \\
Neighbourhood change & $0.562^{* *}(2.177)$ & $0.586^{* *}(2.174)$ \\
Inflation & $-0.0007(0.835)$ & $0.0058^{* * *}(4.85)$ \\
Election & $-0.314(1.087)$ & $-0.364(1.22)$ \\
Constant & $-2.954^{* * *}(11.612)$ & \\
Log-likelihood & -295.255 & -194.117 \\
Number of observations & 1,392 & 1,392 \\
Fixed effects? & No & Yes \\
& & 48 states \\
& & 29 years \\
\hline
\end{tabular}

Note: Absolute values of $t$-statistics are reported in parenthesis.

* Statistical significance at the $10 \%$ level.

** Statistical significance at the 5\% level.

${ }^{* * *}$ Statistical significance at the $1 \%$ level. 
Table 4. Estimation results. Dependent variable is the change in cigarettes tax rate

\begin{tabular}{lcc}
\hline Variable & Pooled model & Panel data binomial logit \\
\hline Log (number of previous changes) & $0.022(0.609)$ & $-0.083^{* *}(2.1)$ \\
Neighbourhood change & $1.071^{* * *}(7.15)$ & $1.141^{* * *}(7.2)$ \\
Inflation & $-0.002(1.369)$ & $0.0051^{* * *}(3.202)$ \\
Election & $-0.204(1.186)$ & $-0.271(1.55)$ \\
Constant & $-2.30^{* * *}(16.74)$ & -493.2 \\
Log-likelihood & -615.8 & 1,632 \\
Number of observations & 1,632 & Yes \\
Fixed effects? & No & 48 states \\
& & 34 years \\
\hline
\end{tabular}

Note: Absolute values of $t$-statistics are reported in parenthesis.

* Statistical significance at the $10 \%$ level.

** Statistical significance at the $5 \%$ level.

${ }^{* * *}$ Statistical significance at the $1 \%$ level.

increases in the neighbouring states (Reed, 2006). The election year does not influence the decision to change tax rates for beer or cigarettes.

\section{Robustness Test}

Duration analysis: survival and hazard curves

A hazard model is used to estimate the time it takes for a change to happen. One can expect that the longer the time after the last change the more likely it is that the tax rate will be changed the following year. On the other hand, if the tax rate has remained unchanged for a long period of time, it may signal an adequate tax level and hence the less likely it is that there will be a change in the near future. Alternatively, a long period with no change may suggest that it is difficult to introduce change. Duration analysis is the preferred method to estimate such phenomena because of its ability to handle right-censored data - we do not observe changes beyond the end of our data.

Duration analysis is sometime called 'time until failure' since it was originally used by engineers to test durability of devices or biomedical researchers to test survival rates after medical procedures. Only relatively recently, social scientists have discovered the usefulness of duration analysis in modelling, for example, time until business failure (Bandopadhyaya \& Jaggia, 2001), length of unemployment spells (Kupets, 2006), or intervals between purchases (Raymond, Beard, \& Gropper, 1993).

To proceed more formally, let $T$ be a non-negative random variable representing the waiting time until the change occurs. We will assume that $T$ has a continuous probability distribution $f(t)$, where $t$ is a realization of $T$ (Greene, 2003). We define a duration spell of $n$ observations as the time it takes for the change to occur (or censored time at the end of the data): $t_{1}, t_{2}, \ldots, t_{n}$. The cumulative distribution function is $F(t)=\operatorname{Prob}(T \leq t)=\int_{0}^{t} f(s) \mathrm{d} s$. Its complement $S(t)=1-F(t)=$ $\operatorname{Prob}(T \geq \mathrm{t})$ is called the survivor function. For example, $S(5)$ is the probability 
that the spell is of length at least 5 or, in other words, the probability that the tax rate has not been changed for 5 years. Now, we can define the hazard rate as the conditional probability that the tax rate will be changed in a short time interval $\Delta t$ following period $t$, given that it was not changed (survived) up to period $t: \lambda(t)=$ $f(t) \Delta t / S(t)$. We say that the hazard rate is the rate at which spells are completed after duration $t$, given that they last at least until $t$. Note that since we have to end our observation at a certain year for some observations spells will not end - the data are right-censored.

Our dependent variable measures the length of time between changes: how long states 'survive' between changes. As explained above, this variable is called a spell, and it is simply the number of years for which states 'survive' without change. ${ }^{5}$ We want to show how our covariates (as regressors are usually called in the duration literature) affect the duration of spells at any particular time (how they affect the 'hazard of dying', i.e. changing taxes).

We present estimations of the hazard and survivor functions using the KaplanMeier estimator (assuming nothing about the underlying distribution of duration spells and without considering any covariates) followed by the estimations of the logistic hazard models.

\section{Results for beer tax rates}

Figure 3 shows the estimated Kaplan-Meier survival function and Figure 4 the estimated hazard function for beer excise tax rates. The survival function shown in Figure 3 is the probability that a state will not change its tax rate for at least $t$ years.

As expected, the survival function is a decreasing function of duration. As illustrated at the end of the graph, about $15 \%$ of spells lasted more than 45 years.

The hazard rate, presented in Figure 4, is the probability that a state will change its beer tax rate in year $t+1$ given that it has not changed it until year $t$ (where $t$ was from 1 to 47 years). The hazard function oscillates in the range from 0 to 0.13 . The conditional probability that a state will not change its beer tax rate the next year, given that it has not changed it for 47 years is nearly $0 \%$. We present the results of the estimation of the beer tax rates via Cox's proportional hazard

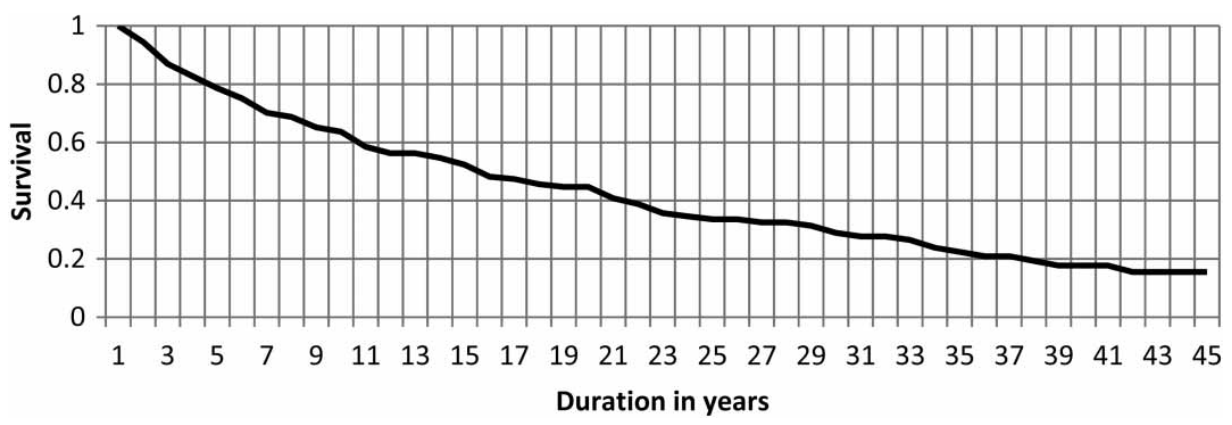

Figure 3. Estimated survival function for beer tax rates. 


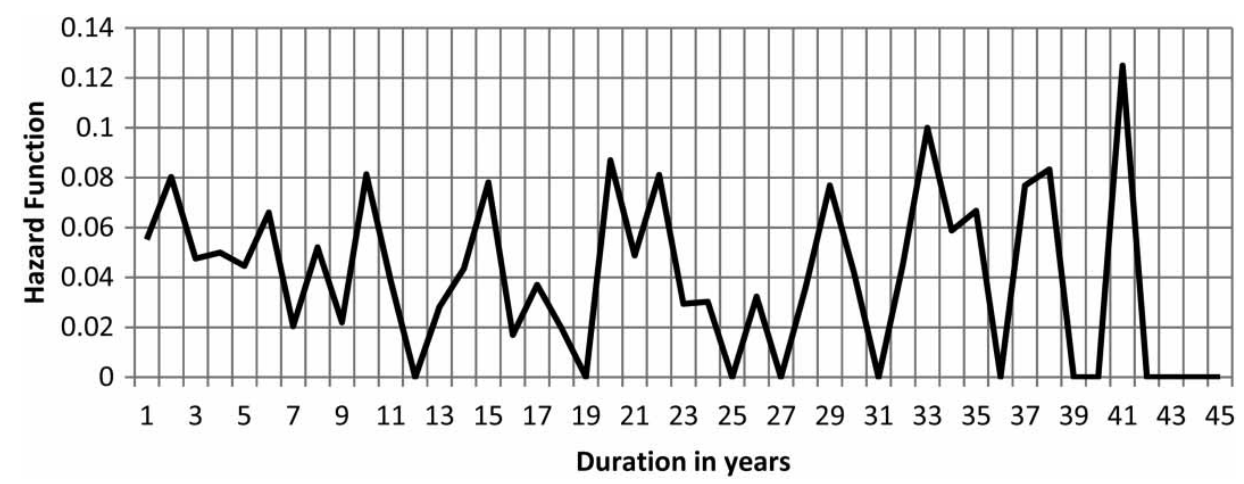

Figure 4. Kaplan-Meier hazard function (time to change beer tax rates).

model in Table 5. The number of censored observations reported at the bottom of Table 5 is the number of spells that lasted beyond the last year in our data set.

The results of the estimation confirm our results from the previous section. The coefficient on the logarithm of the number of previous changes is positive. Therefore, the time between changes is longer if there were more changes in the past. This was expected since our results from the logit estimation reported in the previous section indicated that prior changes of a given type decrease the likelihood of a subsequent change. Therefore, once again, we confirmed the deceleration hypothesis of organizational change. Also, the results confirm that states take into consideration the actions of neighbouring states in making their own decisions: if there is a change in neighbouring states, the time it takes for its own change is shorter. Additionally, the election variable is significant, showing that the time since the last change will be longer in election years. Note, that the inflation variable is not included in the regression since the dependent variable is the number of years for which states did not change their taxes (it takes the value of 1 in the year following the change, 2 in the next year, and so on) and the inflation is the percentage change in CPI from the last year the rate was changed (it resets the year following the

Table 5. Cox's proportional hazard model for beer tax rates. Dependent variable is the number of years from the last change

\begin{tabular}{lc}
\hline Variable & Coefficients \\
\hline Log (number of previous changes) & $0.139^{* * *}(3.16)$ \\
Neighbourhood change & $-0.414^{* *}(1.94)$ \\
Election & $0.627^{* * *}(2.44)$ \\
Log-likelihood & -422.465 \\
Number of observations & 145 \\
Number of obs. exiting & 102 \\
Number of obs. censored & 43 \\
\hline
\end{tabular}

Note: Absolute values of $t$-statistics are reported in parenthesis.

* Statistical significance at the $10 \%$ level.

** Statistical significance at the $5 \%$ level.

${ }^{* * *}$ Statistical significance at the $1 \%$ level. 


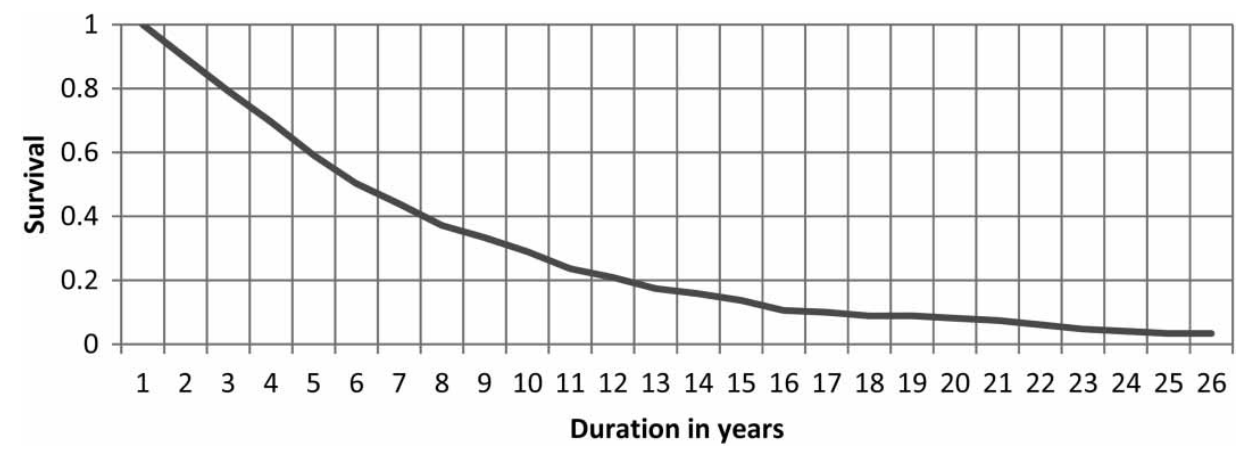

Figure 5. Estimated survival function for cigarette tax rates.

change). By their very nature, these variables measure very similar things and, as expected, they correlate with coefficient 0.9 .

\section{Results for cigarette tax rates}

For cigarette tax rates, the survival function (Figure 5) shows that only $10 \%$ of the spells lasted more than 16 years and almost none of them lasted more than 26 years.

The hazard rate (Figure 6) shows that the probability that states will change their cigarette tax rates is about 0.15 given that they have not changed them from 1 to 14 years and it is pretty stable over this time period.

The hazard rate peaks at 15 years to the probability of about 0.23 when it starts to decrease up to year 18 . Afterwards, it peaks again at 23 years to the probability of 0.23 . It reaches zero at 26 years: the conditional probability that a state will not change its tax next year, given that it has not changed it for 26 years is about zero. We present the results of the estimation of the Cox's proportional hazard model for cigarette tax rates in Table 6.

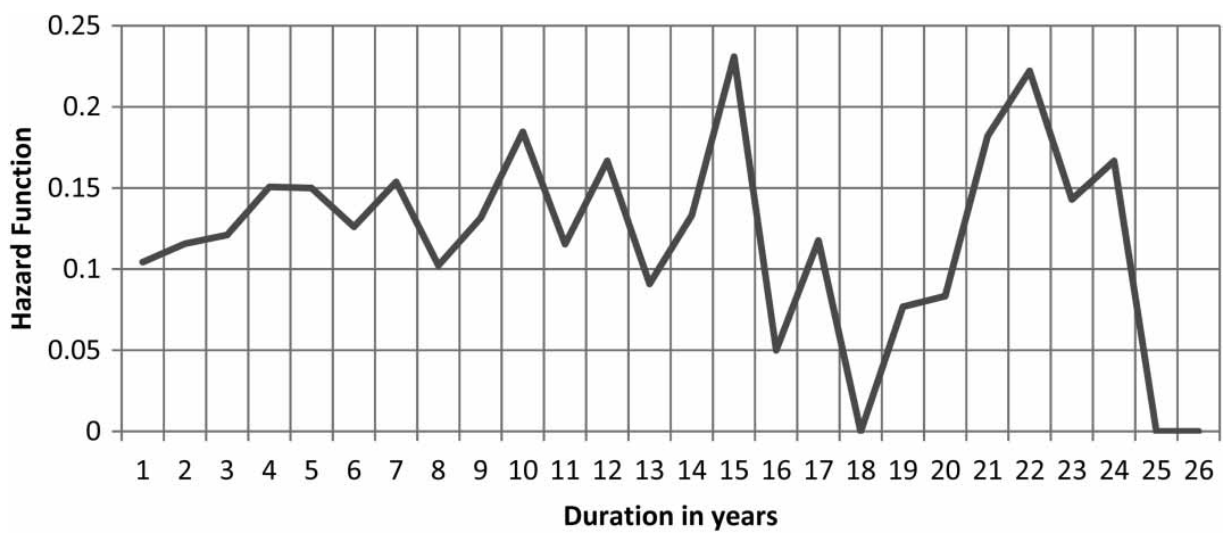

Figure 6. Kaplan-Meier hazard function (time to change cigarette tax rates). 
Table 6. Cox's proportional hazard model for cigarette tax rates. Dependent variable is the number of years from the last change

\begin{tabular}{lc}
\hline Variable & Coefficients \\
\hline Log (number of previous changes) & $0.105^{* * *}(3.22)$ \\
Neighbourhood change & $-0.330^{* *}(2.32)$ \\
Election & $0.302^{*}(1.89)$ \\
Log-likelihood & $-1,021.657$ \\
Number of observations & 249 \\
Number of obs. exiting & 220 \\
Number of obs. censored & 29 \\
\hline
\end{tabular}

Note: Absolute values of $t$-statistics are reported in parenthesis.

* Statistical significance at the $10 \%$ level.

** Statistical significance at the $5 \%$ level.

*** Statistical significance at the $1 \%$ level.

Again, the results from the estimation confirm our results from the logistic model presented in the previous section. The time between changes in states cigarette tax rates is statistically significantly longer if there were more previous changes in the past, confirming the deceleration hypothesis of organizational change. This time is also longer if there is an election in the state. However, it is significantly shorter if there is a change in tax rates in the neighbouring states.

\section{Discussion and Conclusion}

The aim of this study was to find how the probability of future organizational change is affected by the duration between changes, the number of previous changes, and the surrounding environment. We investigated change in public organizations using data on US states beer and cigarette tax rates. The main results of our empirical analyses are that the rules revision rate increases with duration and changes in surrounding conditions but decreases with the number of prior rules changes of the same type. We confirmed these effects by using duration models with fixed effects to conduct hypotheses testing of three research questions. We discuss each question below.

Previous theoretical and empirical studies have not provided a definitive answer regarding the effect of duration between changes on the probability that a future change occurs. The institutional theory claims that the likelihood of rule changes should decrease with duration (waiting time between changes). This dominant hypothesis asserts that structures become increasingly persistent the longer they are around. On the other hand, the organizational learning theory claims that, as time passes and surrounding conditions change, the rules become obsolete and must be updated. In our Research Question no. 1, we asked whether rule obsolescence triggers change. Using two data sets, we found that as time passes there is a higher probability that a change occurs (even after controlling for the number of previous changes and other external characteristics). Therefore, we found support for the organizational learning theory. One can suspect that as rules get older they increasingly contain obsolete instructions 
and need to be changed. However, this effect can only be uncovered when proper methodology is used to avoid confounding effects. The fixed-effect model allows one to avoid the bias due to unobserved heterogeneity and is instrumental in providing support for the organizational learning theory.

There is no agreement in literature about the effect of the number of previous changes on the propensity to change. Again, two opposite theories exist. Most cited is the repetitive momentum hypothesis positing that numerous prior changes of a given type increase the likelihood of a subsequent change of the same type. However, more recently, Beck, Brüderl, and Woywode (2008) proposed the deceleration hypothesis that states that prior changes of a given type decrease the likelihood of a subsequent change of the same type. We provide support for the latter, answering our Research Question no. 2. Based on two data sets, this empirical study provides supporting evidence for the deceleration hypothesis, which is to say that experience in adjusting rules increases the stability of those rules. Again, the phenomenon can only be uncovered by using the fixedeffects model. This model is absent in studies supporting the repetitive momentum hypothesis, leaving a possibility that those studies were skewed by unobserved heterogeneity.

Finally, our research suggests that environmental changes increase the likelihood that future change will occur. As before, two complementary scenarios are plausible. First, rules may have to be updated in response to changing outside or inside conditions or opportunities. Second, change of rules may be less likely to occur when, for example, they become the cornerstone of core competencies of organizations, or a source of accountability and reliability, or when they become the foundation for other rules created at later points in time (Schulz, 1998). Our empirical results, answering Research Question no. 3, lean towards the former: rules changes are more likely to happen with shifts in surrounding conditions.

\section{Limitations}

Our study uses data on US states beer and cigarette taxes set by the state legislators. Therefore, the results may not generalize to all organizations and all types of rules. In particular, private organizations may behave differently than the states, depending on their size and the nature of their business.

Changes in public sector are often considered to be more difficult to implement than changes in the private sector (Bendell, Boulter, \& Kelly, 1994; McAdam \& Saulters, 2000; Robertson \& Senevirante, 1995). Compared with the private sector, the public arena is more political, requiring consensus of many players. It is also more tightly governed by rules, regulations, and procedures (Korunka, Scharitzer, Carayon, \& Sainfort, 2003). The process of increasing tax rates starts at state government committees that review legislation and make recommendations. Then, to become a law, a bill must be passed in both houses and signed by the Governor. On the other hand, in business organizations, managers can change the rules more easily, often single handedly. However, a more substantial change usually does not happen without support of the key stakeholders, making the process somewhat similar to that in public 
sector. These are the types of change scenarios to which our results most likely apply.

The key advantage of using data on state taxes is that data on rule changes of the same type in private organizations are not easily available, especially for such a long period of time. Other studies on the subject of organizational change used government or university data. This includes studies published in this journal by Baraldi et al. (2010) and Drzensky, Egold, and Van Dick (2012). As these authors pointed out, there is a need to study change in public organizations. Even if it may be questionable whether patterns of behaviour pertaining to state taxes are universally generalizable elsewhere, it can be argued that shedding light on behaviour of state governments is of sufficient economic, social, and cultural importance to justify this study on its own.

Another limitation of our analyses is that they only considered changes related to raising economic costs (higher taxes and not lower taxes). In a broad organizational setting, changes are more varied: for example, not always burden increasing and not always economic.

Finally, institutional theory provides very strong argument for the permanence position that the rule version becomes increasingly permanent and the likelihood of rule changes decreases with duration. In reality, both mechanisms: permanence and obsolescence may coexist at the same time. Therefore, the institutional effects may conspire to decrease the odds of change making the estimated coefficient on 'inflation' lower than it would be in absence of the institutional effects. This mechanism is undetectable with our data set since inflation is always present. Future studies should aim to detect this effect using different data and methods.

In light of these limitations, further testing of our hypotheses should be conducted by employing methodologies similar to ours and using data sets pertaining to different types of rules and spanning a broader spectrum of settings (public and private).

Additionally, one possible improvement on our work (albeit requiring different methods) would entail accounting for the size of the change (how much the tax rate was increased). It has been suggested that organizations undergo a fundamental reorientation of structures at some point in life (Gersick, 1991; Lant \& Mezias, 1992; Tushman \& Romanelli, 1985). Amis, Slack, and Hinings (2004) argued that rapid large-scale changes that are simultaneous across a whole organization may be ineffective and disruptive. On the other hand, the better the outcomes of such changes, the less need will there be for future changes (Beck, Brüderl, \& Woywode, 2008). It remains to be seen if our findings hold true for such fundamental reorientations.

\section{Implications}

Subject to the limitations discussed above, our study makes an important contribution to the management literature by lending support for the deceleration hypothesis and the organizational learning theory. We adopted a discerning analytical approach by using fixed effects and duration models to study rule changes. We also analysed a much longer sample compared to previous studies. 
In any case, ours is one of few studies investigating change in public organizations, filling an important gap in literature.

The negative effect of the number of past changes on the likelihood of future change of the same type was explained by Beck, Brüderl, and Woywode's (2008) deceleration hypothesis. On average, organizations that change rules more often in the past, set rules that do not require updating for a longer period of time (Beck, Brüderl, \& Woywode, 2008). We found support for the deceleration hypothesis. Our results suggest that analysing and learning from successful rule change initiatives is important in improving rule efficiency. When change is aimed at improving organizational structures and processes, updating rules of the same type may not be necessary for a longer period of time.

Schulz $(1992,1998,2003)$ described the concept of the obsolescence clock when each revision of the rule re-starts the clock. As time passes and surrounding conditions change, organizations must adapt, leading to increased probability that a successful future change initiative will happen. Our study indicates that, on average, rules are not allowed to become obsolete and successful change initiatives are undertaken. Organizations need to constantly monitor changes in their environments and determine if they need to adjust. Our results indicate that, as time passes, organizations are able to successfully pass change initiatives.

Our results also confirm that shifts in surrounding conditions increase the probability of change. For state legislators, the most important implication is that a legislation effecting the change is easier to pass when the neighbouring states adopted similar legislations. One expects that it should be easier to find support for change inside an organization when peer organizations change rules of similar type.

Finally, the results of this study have strong implications for future research on organization change. Our results suggest strong history dependence in change rates (e.g. frequency of changes and the passage of time between changes). Research that does not account for the organizational history and past experiences with change would provide an incomplete and potentially flawed picture of organizations (as also postulated by Amburgey et al., 1993). Equally strong is evidence for using fixed effects while studying change. If omitted, the results may be incorrect and misleading.

We believe our paper follows the call from Pfeffer (2007, p. 1334) for management research to be 'influential in the formulation of policy in both the public domain and private sector ... and more specifically, on a par with economics'.

\section{Notes}

1. For the comprehensive literature review, see Beck, Brüderl, and Woywode (2008).

2. Other papers on the subject include Besley and Rosen (1998), Case, Rosen, and Hines (1993), Besley and Case (1995), Heyndels and Vuchelen (1998), Wu and Hendri (2009), and Brueckner and Saavedra (2001).

3. The number of data points used in regressions is shorter in order to calculate the time from the last change.

4. Beer taxes vary by alcohol content (e.g. 3.2 beer vs. stronger beer), size of container (e.g. cans vs. barrels), and on-premise vs. off-premise. For problems on finding a uniform tax rate measure see Young and Bielinska-Kwapisz (2002, 2003, 2006).

5. It takes a value of 1 in the year following the change, of 2 in the next year, and so on. 


\section{References}

Amburgey, T. L., Kelly, D., \& Barnett, W. P. (1993). Resetting the clock. The dynamics of organizational change and failure. Administrative Science Quarterly, 38, 51-73.

Amis, J., Slack, T., \& Hinings, C. R. (2004). The pace, sequence, and linearity of radical change. Academy of Management Journal, 47(1), 15-39.

Bandopadhyaya, A., \& Jaggia, S. (2001). An analysis of second time around bankruptcies using a split-population duration model. Journal of Empirical Finance, 8, 201-218.

Baraldi, S., Kalyal, H. J., Berntson, E., Näswall, K., \& Sverke, M. (2010). The importance of commitment to change in public reform: An example from Pakistan. Journal of Change Management, 10(4), 347-368.

Beck, N., Brüderl, J., \& Woywode, W. (2008). Momentum or deceleration? Theoretical and methodological reflections on the analysis of organizational change. Academy of Management Journal, 51(3), 413-435.

Beck, N., \& Kieser, K. (2003). The complexity of rule systems, experience and organizational learning. Organization Studies, 24(5), 793-814.

Bendell, T., Boulter, L., \& Kelly, J. (1994). Implementing quality in the public sector. London: Financial Times/ Pitman.

Besley, T., \& Case, A. (1995). Incumbent behavior: Vote-seeking, tax-setting, and yardstick competition. American Economic Review, 85(1), 25-45.

Besley, T., \& Rosen, H. S. (1998). Vertical externalities in tax setting: Evidence from gasoline and cigarettes. Journal of Public Economics, 70(3), 383-398.

Bielinska-Kwapisz, A. (2011). What determines excise tax rates? Journal of Public Finance and Public Choice, 9(1), 63-85.

Brittain, J. (1989). Strategy and time-dependent failure probabilities: Experience, obsolescence, and strategic change. Academy of Management Best Papers Proceedings, 173-177.

Brueckner, J. K., \& Saavedra, L. A. (2001). Do local governments engage in strategic property-tax competition? National Tax Journal, 54(2), 203-229.

Burnes, B., \& Jackson, P. (2011). Success and failure in organizational change: An exploration of the role of values. Journal of Change Management, 11(2), 133-162.

By, R. T. (2005). Organizational change management: A critical review. Journal of Change Management, 5(4), 369-380.

Case, A. C., Rosen, H. S., \& Hines, J. R. Jr (1993). Budget spillovers and fiscal policy interdependence. Evidence from the states. Journal of Public Economics, 52, 285-307.

Center for Science in the Public Interest (CSPI). (2004). Factbook on state beer taxes. Center for Science in the Public Interest. Retrieved September 27, 2013, from CSPI Alcohol Policies Project: http://www.cspinet.org/ booze/taxguide/040802BeerReport.pdf

Cohen, M. D., March, J. G., \& Olsen, J. P. (1972). A garbage can model of organizational choice. Administrative Science Quarterly, 17, 1-25.

Cyert, R. M., \& March, J. G. (1963). A behavioral theory of the firm. Englewood Cliffs, NJ: Prentice-Hall.

Dacin, M. T., Goodstein, J., \& Scott, W. R. (2002). Institutional theory and institutional change: Introduction to the special research forum. Academy of Management Journal, 45(1), 45-57.

Delacroix, J., \& Swaminathan, A. (1991). Cosmetic, speculative, and adaptive organizational change in the wine industry: A longitudinal study. Administrative Science Quarterly, 36, 631-661.

Devereux, M. P., Lockwood, B., \& Redoano, M. (2007). Horizontal and vertical indirect tax competition: Theory and some evidence from the USA. Journal of Public Economics, 91, 451-479.

DiMaggio, P. J., \& Powell, W. W. (1991). Introduction. In W. W. Powell \& P. J. DiMaggio (Eds.), The new institutionalism in organizational analysis. (pp. 1-38). Chicago, IL: University of Chicago Press.

Dobrev, S. D., Kim, T-Y., \& Hannan, M. T. (2001). Dynamics of niche width and resource partitioning. American Journal of Sociology, 106, 1299-1337.

Drzensky, F., Egold, N., \& Van Dick, R. (2012). Ready for a change? A longitudinal study of antecedents, consequences and contingencies of readiness for change. Journal of Change Management, 12(1), 95-111.

Frantz, D. (2004). Change management. In G. Goethals, G. Sorenson, \& J. Burns (Eds.), Encyclopedia of leadership. (pp. 155-158). Thousand Oaks, CA: Sage Publications. doi: http://dx.doi.org/10.4135/9781412952392.n40

Gersick, C. J. G. (1991). Revolutionary change theories. A multilevel exploration of the punctuated equilibrium paradigm. Academy of Management Review, 16, 10-36.

Greene, W. H. (2003). Econometric analysis (5th ed.). Upper Saddle River, NJ: Prentice-Hall. 
Hammer, M., \& Champy, J. (1993). Reengineering the corporation: A manifesto for business revolution. New York, NY: Harper Collins.

Heyndels, B., \& Vuchelen, J. (1998). Tax mimicking among Belgian municipalities. National Tax Journal, 51(1), $89-101$.

Higgs, M., \& Rowland, D. (2005). All changes great and small: Exploring approaches to change and its leadership. Journal of Change Management, 5(2), 121-151.

Kelly, D., \& Amburgey, T. L. (1991). Organizational inertia and momentum. A dynamic model of strategic change. Academy of Management Journal, 34, 591-612.

Kieser, A., Beck, N., \& Tainio, R. (2001). Rules and organizational learning. The behavioral theory approach. In M. Dierkes, A. B. Antal, J. Child, \& I. Nonaka (Eds.), Handbook of organizational learning (pp. 598-623). Oxford : Oxford University Press.

Kieser, A., \& Walgenbach, P. (2003). Organisation (4th ed.). Stuttgart: Schäffer-Poeschel.

Korunka, C., Scharitzer, D., Carayon, P., \& Sainfort, F. (2003). Employee strain and job satisfaction related to an implementation of quality in a public service organization: A longitudinal study. Work and Stress, 17(1), $52-72$.

Kotter, J. (1990). A force for change: How leadership differs from management. New York, NY: Simon \& Schuster.

Kupets, O. (2006). Determinants of unemployment duration in Ukraine. Journal of Comparative Economics, 34 , $228-247$.

Lant, T. K., \& Mezias, S. J. (1992). An organizational learning model on convergence and reorientation. Organization Science, 3, 47-71.

March, J. G., \& Olsen, J. P. (1976). Ambiguity and choice in organizations. Bergen: Universitesforlaget.

McAdam, R., \& Saulters, R. (2000). Quality measurement frameworks in the public sector. Total Quality Management, 11, 652-656.

McKinsey \& Company. (2008). Creating organizational transformations. The McKinsey Quarterly, July, 1-8. Retrieved from http://gsme.sharif.edu/ change/McKinsey\%20Global\%20Survey\%20Results.pdf.

Nelson, M. A. (2002). Using excise taxes to finance state government: Do neighboring state taxation policy and cross-border markers matter? Journal of Regional Science, 42, 731-752.

Nelson, R. R., \& Winter, S. G. (1982). An evolutionary theory of economic change. Cambridge: Belknap Press.

Ocasio, W. (1999). Institutionalized action and corporate governance. The reliance on rules of CEO succession. Administrative Science Quarterly, 44, 384-416.

Parry, W., Kirsch, C., Carey, P., \& Shaw, D. (2013). Empirical development of a model of performance drivers in organizational change projects. Journal of Change Management, 1-27. Advance online publication. doi:10. 1080/14697017.2012.745894.

Pettigrew, A. M., Woodman, R. W., \& Cameron, K. S. (2001). Studying organizational change and development: Challenges for future research. Academy of Management Journal, 44(4), 697-713.

Pfeffer, J. (2007). A modest proposal: How we might change the process and product of managerial research. Academy of Management Journal, 50(6), 1334-1345.

Ponicki, W. R. (2004). Statewide availability data system II: 1933-2003. National Institute on Alcohol Abuse and Alcoholism Research Center Grant P60-AA006282-23. Berkeley, CA: Pacific Institute for Research and Evaluation, Prevention Research Center.

Raymond, J. E., Beard, T. R., \& Gropper, D. M. (1993). Modeling the consumer's decision to replace durable goods: a hazard function approach. Applied Economies, 25, 1287-1292.

Reed, W. R. (2006). Democrats, republicans, and taxes: Evidence that political parties matter. Journal of Public Economics, 90, 725-750.

Robertson, P. J., \& Senevirante, S. J. (1995). Outcomes of planned organizational change in the public sector: A meta-analytic comparison to the private sector. Public Administration Review, 55(6), 547-558.

Rogers, P., Meehan, P., \& Tanner, S. (2006). Building a winning culture. Boston, MA: Bain.

Rork, J. K. (2003). Coveting thy neighbors' taxation. National Tax Journal, 56, 775-787.

Schulz, M. (1992). A depletion of assets model of organizational learning. Journal of Mathematical Sociology, $17,145-173$.

Schulz, M. (1998). A model of obsolescence of organizational rules. Computational \& Mathematical Organization Theory, 4(3), 241-266.

Schulz, M. (2003). Impermanent institutionalization: the duration dependence of organizational rule changes. Industrial and Corporate Change, 12(5), 1077-1098. 
Schulz, M., \& Beck, N. (2000). Iron laws of bureaucracy-comparing incremental and radical change of organizational rules in the U.S. and in Germany. Unpublished manuscript. Columbia: Sauder School of Business, University of British.

Tushman, M. L., \& Romanelli, E. (1985). Organizational evolution. A metamorphosis model of convergence and reorientation. In B. M. Staw \& L. L. Cummings (Eds.), Research in organizational behavior (pp. 171-222). Greenwich, CT: JAI Press.

Weber, M. (1968). Economy and society. An outline of interpretative sociology. (G. Roth \& C. Wittich Eds.). New York, NY: Bedminster.

Wu, Y., \& Hendri, R. (2009). Horizontal and vertical tax competition in Florida local governments. Public Finance Review, 37(3), 289-311.

Young, D. J., \& Bielinska-Kwapisz, A. (2002). Alcohol taxes and beverage prices. National Tax Journal, LV-1, 57-73.

Young, D. J., \& Bielinska-Kwapisz, A. (2003). Alcohol consumption, Beverage prices and measurement error. Journal of Studies on Alcohol, 64(2), 235-238.

Young, D. J., \& Bielinska-Kwapisz, A. (2006). Alcohol prices, consumption and traffic fatalities. Southern Economic Journal, 72(3), 690-703.

Zucker, L. G. (1987). Institutional theories of organization. Annual Review of Sociology, 13, 443-464. 